\title{
Upper Lip Vermilion Transposition Flap pada Commisuroplasty dan $Z$ Plasty pada Rekonstruksi Macrostomia
}

\section{Iswinarno Doso Saputro ${ }^{*}$ (iD}

aDepartment of Plastic Reconstructive and Aesthetic Surgery, Faculty of Medicine Universitas Airlangga *Corresponding author: Iswinarno Doso Saputro - Department of Plastic Reconstructive and Aesthetic Surgery, Faculty of Medicine Universitas Airlangga

\section{ARTICLE INFO}

Kata Kunci:

Macrostomia

*Corresponding author

Iswinarno Doso Saputro

Email address:

iswinarno@yahoo.com

\section{History:}

Received: 10 Oktober 2021

Accepted: 16 November 2021
ABSTRACT

Macrostomia adalah kelainan kongenital yang jarang terjadi, biasanya disertai kelainan lain. Kelainan ini diperkirakan terjadi pada 1 dari 80.000 kelahiran. Beberapa literatur telah menjelaskan tehnik operasi rekontruksi macrostomia, meski emikian belum ada satu standart operasi yang rekomendasikan, setiap tehnik memiliki kelebihan dan kekurangan. Penulis melaporkan satu kasus operasi rekontruksi macrostomia dengan menggunakan tehnik Kaplan untuk comisuroplaty, otot dijahitkan secara overlapping serta menggunakan Zplasty untuk penutupan kulit.

\section{Pendahuluan}

$\mathrm{M}$ acrostomia atau sering disebut juga sebagai transverse facial cleft adalah suatu kelainan sejak lahir dimana mulut penderita lebih lebar dari ukuran normal rata-rata. Kelainan ini dapat ke satu sisi (unilateral), atau kedua sisi (bilateral). Macrostomia dapat isolated atau dapat sebagai bagian suatu sindrom, misalnya treacher collin sindrom atau suatu hemifacial mikrosomia. Kelainan yang sering menyertai macrostomia adalah adanya tragus asesorius pada sisi arah telinga, dapat juga diertai dengan clef lip atau nasal cleft. 1,2

Kelainan ini diperkirakan terjadi saat embryonal dimana terjadi kegagalan penyatuan prosesus mandibula dan maksila. Kelainan ini sering disebut juga sebagai commissural atau lateral facial cleft (Tessier 7 soft tissue). ${ }^{3}$ Kelainan ini didapatkan pada 1 dari 80.000 kelahiran, sering berjenis kelamin laki laki. Lebih sering ditemukan dalam bentuk unilateral, bilateral hanya sekitar 10-20\%. Kelainan ini sering di diagnose banding dengan Treacher Collins Syndrome dan Hemifacial microsomia. 4,5

Belum ada teknik khusus yang menjadi pedoman pada operasi rekonstruksi kelainan ini, namun tujuan dari operasi rekonstruksi adalah tercapainya bentuk mulut yang simetris serta fungsi yang optimal, selain penampilan estetik yang baik. $^{5}$ Pada laporan kasus ini akan dilaporkan pengalaman operasi rekontruksi macrostomia unilateral isolated, dengan disertai tragus asesorius pada seorang anak perempuan umur 5 tahun.

\section{Material dan method}

Pasien wanita umur 5 tahun, dengan keluhan utama mulut sebelah kiri lebih lebar dibanding kan sebelah kanan. Merupakan anak pertama dari 2 bersaudara, saudaranya normal. Tidak ada Riwayat trauma selama dalam masa 
kehamilan, minum obat dan jamu disangkal. lahir normal sesuai dengan masa kehamilan, ditolong oleh bidan. Status imunisasi lengkap, pertumbuhan dan perkembangan normal, sesuai dengan umur dan berat badan.

Pada pemeriksaan fisik didapatkan mulut yang lebih lebar dari ukuran normal, dan didapatkan benjolan pada pipi didepan telinga. Pemeriksaan lainnya dalam batas normal.pemeriksaan foto thorak dan mandibula serta maxilla dalam batas normal.

Prosedur operasi :

Informed consent ditandatangani oleh orang tua penderita, posisi operasi terlentang. Dilakukan marking dan pengukuran jarak bibir normal $(2,7 \mathrm{~cm})$ dan jarak bibir abnormal $(4 \mathrm{~cm})$. Kemudian dibuat desain insisi. Setelah itu dilakukan pembiusan dengan tube diletakkan di tengah bibir bawah, dilakukan tanpa merubah bentuk bibir bawah, kemudian dilakukan fiksasi tube dengan plester yang kuat. Setelah itu dilakukan desinfeksi dengan antiseptic dan dipersempit lapangan operasi dengan kain steril. Kemudian dilakukan injeksi dengan campuran epineprin $1 / 200.000$ dan lidokain. Dilakukan insisi sesuai desain, dan dilanjutkan dengan eksisi vermilion bibir bawah, mukosa serta prmbebasan otot orbicularis oris atas dan bawah, sementara vermilion bibir atas dibuat flap yang kemudian diputar ke bawah dan diletakan divermilion bibir bawah. Dilakukan pengukuran ulang untuk memastikan sudah simetris. Kemudian dilakukan perawatan perdaharan dan penjahitan, pada mukosa, otot, dan comisura. Pada kulit dibuat desain Z-plasty dan dilakukan penutupan kulit dengan Z-Plasty. Luka kemudian dirawat dengan salep mata gentamicin.
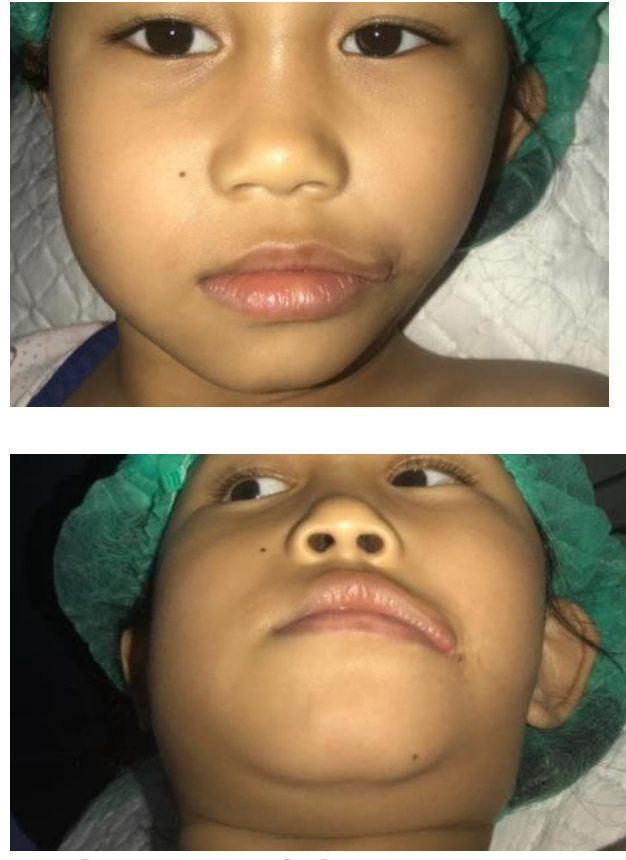

Gambar 1. Foto sebelum operasi


Gambar 2. Foto durante operasi 

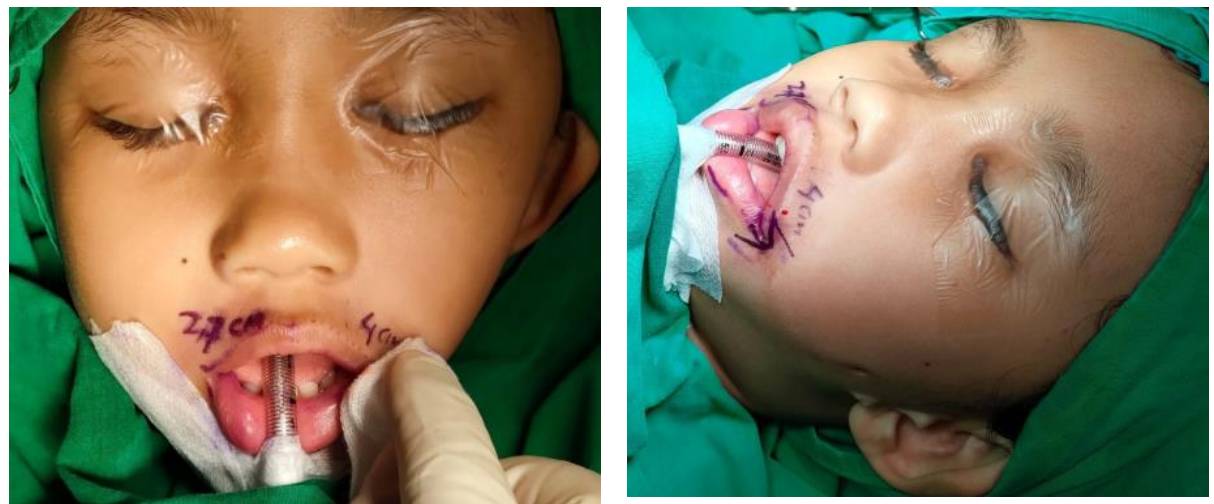

Gambar 3. Foto ukuran Jarak sisi normal $2,7 \mathrm{~cm}$, jarak sisi abnormal $4 \mathrm{~cm}$ serta desain Z plasty
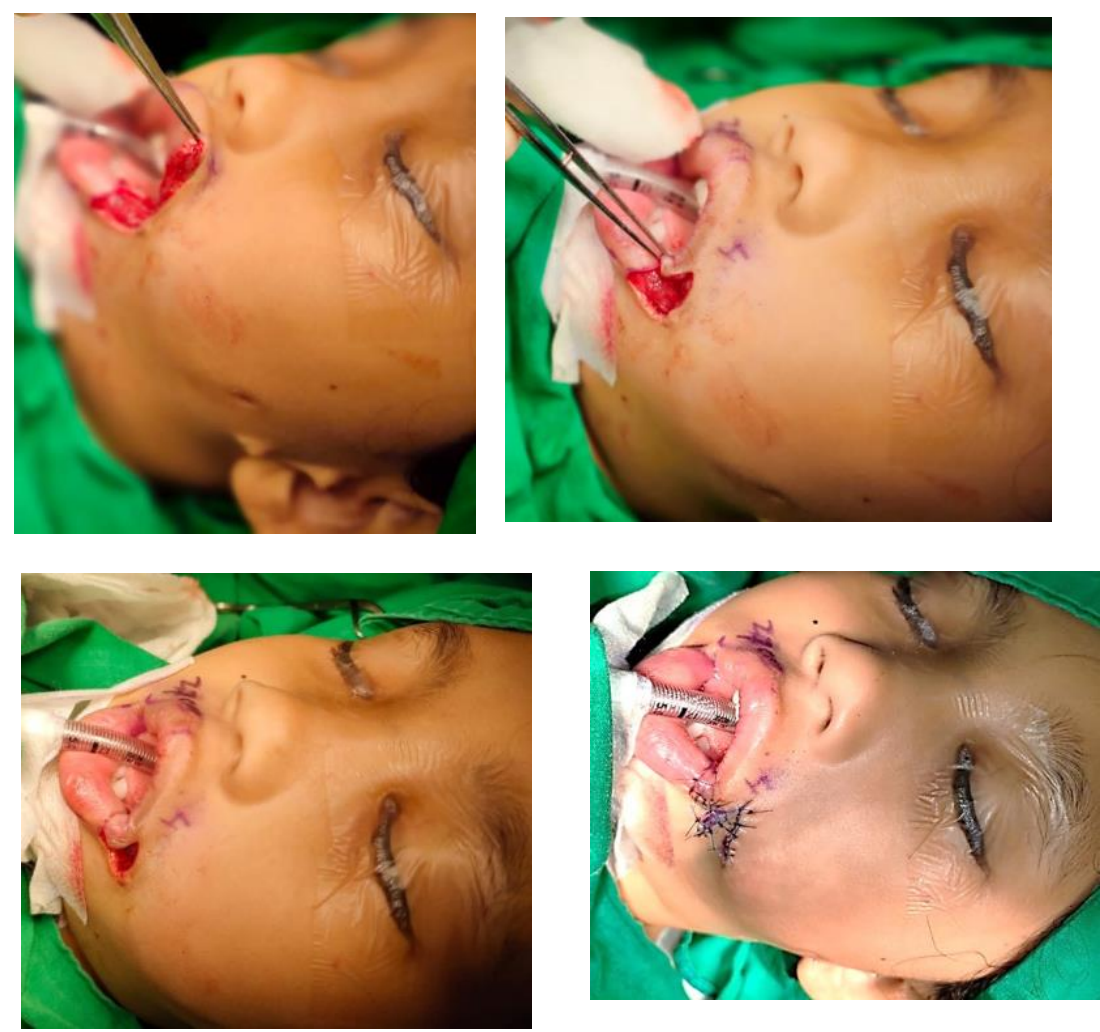

Gambar 4. Foto hasil operasi

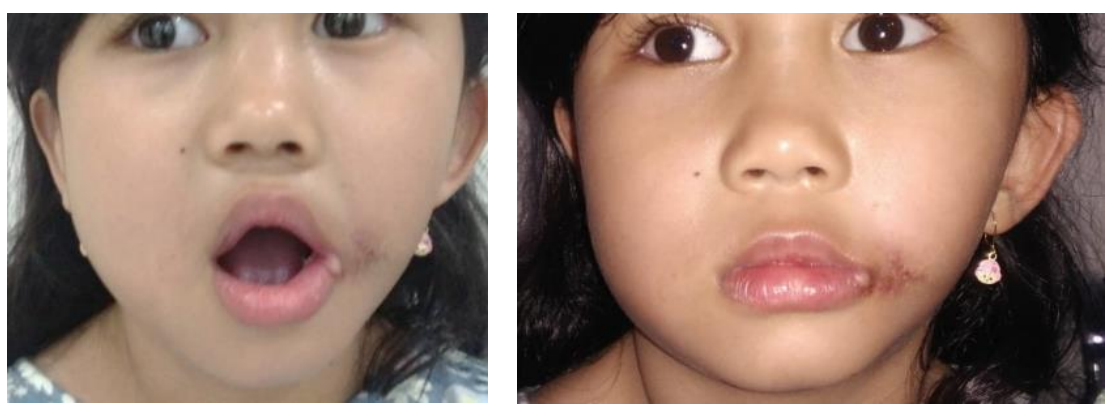

Gambar 5. Foto 15 hari setelah operasi 


\section{Diskusi}

Tujuan operasi pada rekonstruksi pada macrostomia adalah menghasilkan fungsi orbicularis oris yang lebih baik, serta penampakan estetik yang bagus. ${ }^{5}$ Ada 3 hal yang perlu diperhatikan pada operasi macrostomia (transverse facial cleft), yaitu memperbaiki otot orbicularis oris (myoplasty), commisuroplasty, menata mukosa dan kulit. ${ }^{6}$

Menurut Boo-Chai tahun 1969, otot orbicularis oris atas dan bawah harus dijahitkan dengan tepat sehingga menghasilkan bentuk dan fungsi mulut yang baik. ${ }^{7}$ Penjahitan kulit dapat dilakukan secara linier atau dengan $\mathrm{Z}$ atau $\mathrm{W}$ plasty. Penjahitan secara linier lebih sering menyebabkan lateral migrasi dari comisura serta hipertropik scar dan kontraktur dibandingkan dengan penggunaan tehnik $\mathrm{Z}$ atau W plasty. 8,9

Terdapat 3 teknik commisuroplasty (teknik dari Kaplan), yaitu teknik pertama dengan menggunakan upper lip vermilion yang ditransposisikan ke lower lip untuk membentuk neocomisura. ${ }^{10}$ Teknik kedua yaitu teknik dari Kajiwaka yang menggunakan metode end to end anastomosis untuk membentuk neocomisura. ${ }^{11}$ Teknik ketiga yaitu teknik dari Onizuka, dimana menempatkan flap kulit diantara upper dan lower vermilion. ${ }^{12}$

$$
\text { Pada kasus ini penulis }
$$

menggunakan teknik kedua, yaitu menggunakan upper lip vermilion yang ditransposisikan ke lower lip vermilion. Menurut penulis dengan tehnik ini didapatkan hasil comisura yang lebih natural dan lebih simteris. Pada kasus ini otot orbicularis oris dijahitkan sesuai dengan teknik Boo-Chai, sehingga fungsi otot dapat lebih optimal. Penutupan kulit pada kasus ini dengan menggunakan teknik $\mathrm{Z}$ plasty karena dengan teknik ini dapat mencegah terjadinya migrasi ke lateral dari comisura.

\section{Kesimpulan}

Pada kasus Macrostomia unilateral simple teknik operasi untuk comisuroplasty dapat digunakan tehnik dari Kaplan yaitu menggunakan upper lip vermilion flap yang ditransposisikan ke vermilion bibir bawah dimana pada kasus ini dapat memberikan hasil comisura yang lebih natural dan tidak terjadi kontraktur serta migrasi comisura lateral. Untuk otot dilakukan penjahitan dengan teknik Kajiwaka, menghasilkan fungsi otot yang mendekati normal. Untuk penutupan kulit dilakukan dengan Z plasty, menghasilkan scar yang secara estetik lebih baik.

\section{Ucapan terima kasih :}

Terima kasih kepada dr Ari Pratama yang sudah membantu dalam penelusuran referensi, serta kepada dr Burhan yang telah melakukan dokumentasi dan menjadi asisten dalam operasi pasien ini.

\section{Referensi}

1. Buonocore S, Broer PN, Walker ME, et al. Macrostomia, A Spectrum of Deformity. Annals Plastic Surgery. 2014;72(3):363368.

2. Ibrahim A, Ali G, Kutlu S, et al. Lateral facial cleft (Macrostomia). Ann Plast Surg. 2013;355-6.

3. Askar I, Gurlek A, Sevin K. Lateral Facial cleft (macrostomia). Plast Reconstr Surg. 2001;47:355-356.

4. Mohan RPS, Verma S, Agarwal N, et al. Case report Bilateral macrostomia. BMJ Case Rep. 2013. doi:10.1136/bcr-2013010429.

5. Kobraei EM, Lentz AK, Eberlin KR, et al. Macrostomia : A Practical Guide for Plastic and Reconstructive Surgeon. The Journal of Craniofacial Surgery. 2015;27(1):118-123.

6. Gunturu S, Nallamothu R, Kodali RM, et al. Macrostomia: A Review of Evolution of Surgical Technique. Hindawi Publishing Co. artikel. 2014. 
http://dx.doi.org/10.1155/2014/47135

3.

7. Boo-Chai K. The transverse facial cleft: its repair. British Journal of Plastic Surgery. 1969;22(2):119-124.

8. Zhou L, Zhu H, Shi D, et al. Transverse facial cleft (macrostomia) repair: modification of traditional technique. Journal of Plastic, Recontructive \& Aesthetic Surgery. 2019; 1-8.

9. Franco D, Franco T, da Silva Freitas R, et al. Commissuroplasty for macrostomia. $J$ Craniofac Surg. 2007;18:691-694.
10. Kaplan EN. Commissuroplasty and myoplasty for macrostomia. Annal of Plastic Surgery. 1981;7(2):136-144.

11. Kawai T, Kurita K, Echiverre NV, et al. Modified technique in surgical correction of macrostomia. Int J Oral Maxillofac Surg. 1998;27:178-180.

12. Yoshimura Y, Nakajima T, Nakanishi Y. Simple line closure for macrostomia repair. British Journal of Plastic Surgery. 1992;45(8):604-605. 